\title{
Perlindungan Hukum Terhadap Hak Cipta Geguritan Bali Di Indonesia
}

\author{
Putu Bagus Dananjaya1, I Gede Pasek Pramana²
}

${ }^{1}$ Fakultas Hukum Universitas Udayana, E-mail: tubagusdananjaya@yahoo.com ${ }^{2}$ Fakultas Hukum Universitas Udayana, E-mail: pasekpramana@gmail.com

\begin{tabular}{l}
\hline Info Artikel \\
\hline Masuk : 25 Oktober 2020 \\
Diterima : 23 November \\
2020 \\
Terbit : 15 Desember 2020 \\
Keywords : \\
Geguritan Bali; Legal \\
protection; Traditional \\
Cultural Expressions; \\
Copyright \\
\\
\\
Kata kunci: \\
Geguritan Bali; \\
Perlindungan hukum; \\
Ekspresi Budaya \\
Tradisional; Hak cipta \\
Corresponding Author: \\
Putu Bagus Dananjaya,E- \\
mail: \\
tubagusdananjaya@yahoo.co \\
m \\
DOI: \\
10.24843/AC.2020.v05.i03.p11 \\
\end{tabular}

\begin{abstract}
Geguritan Bali as a Traditional Cultural Expression whose copyright is held by the State is a provision of Article 38 paragraph (1) of Law Number 28 Year 2014 concerning Copyright. Countries are required to inventory, preserve and preserve traditional cultural expressions. The problemis that the use of traditional cultural expressions is easily claimed to be the domain of other parties who registered and published it earlier. This study aims to analyze legal protection and legal remedies if the Bali Geguritan is reproduced without permission for commercial needs. This study uses a normative legal research method with a statutory approach. The results of this study indicate that the protection of Geguritan Bali's copyright works in the Copyright Act has not been able to protect the expression of traditional culture as a whole because of the blurring of norms and character differences between Intellectual Property Rights and Traditional Cultural Expressions. The Regional Government has the authority to file a lawsuit related to the multiplication of Geguritan Bali without permission for commercial needs. Based on the theory of the authority of the mandate granted by the state as the copyright holder to the Provincial Culture Office and the City Culture Office as the area carrying the Traditional Cultural Expressions.

\begin{tabular}{l}
\hline Abstrak \\
\hline Geguritan Bali sebagai Ekspresi Budaya Tradisional yang hak \\
ciptanya dipegangoleh Negara merupakan ketentuan dari Pasal \\
38 ayat (1) Undang-Undang Nomor 28 Tahun 2014 tentang \\
Hak Cipta. Negara diwajibkan untuk menginventarisasi, \\
menjaga dan memelihara Ekpresi Budaya Tradisional. \\
Masalahnya pemanfaatan ekspresi budaya tradisional dengan \\
mudah diklaim sebagai domein pihak lain yang lebih awal \\
mendaftarkan dan mempublikasinya. Penelitian ini bertujuan \\
untuk mengetahui dan menganalisis pengaturan perlindungan \\
hukumdan upayahukumbila Geguritan Bali diperbanyak tanpa \\
izin guna kebutuhan komersial. Penelitian ini menggunakan \\
metode penelitian hukum normatif dengan pendekatan \\
perundang-undangan. Hasil penelitian ini menunjukan bahwa \\
perlindungan karya cipta Geguritan Bali dalam Undang- \\
Undang HakCipta belum mampu melindungi ekspresi budaya \\
tradisional secara utuh karena adanya kekaburan norma serta \\
perbedaankaraterantaraHak Kekayaan Intelektual dan Ekpresi \\
Budaya Tradisional. Pemerintah Daerah mempunyai \\
kewenangan mengajukan gugatan terkait dengan perbanyakan
\end{tabular}
\end{abstract}


Geguritan Bali tanpa izin untuk kebutuhan komersial. Berdasarkan teori kewenangan mandat yang diberikan negara sebagai pemeganghak ciptakepada Dinas Kebudayaan Provinsi maupun Dinas Kebudayaan Kabupaten Kota sebagai daerah pengemban Ekspresi Budaya Tradisional.

\section{Pendahuluan}

Bali pada pemerintahan Raja Waturenggong banyak memperkenalkan puisi-puisi Majapahit berupa tembang yang disebut dengan macepat. Macepat ini terus mengalami perkembangan dari abad XVII sampai sekarang. Hasil karya sastra dalam bentuk ini disebut dengan geguritan. Geguritan adalah cerita dalam bentuk puisi yang dapat dilagukan dengan Bahasa Bali dan Bahasa Kawi. Karya sastra berupa geguritan sangat digemari di Bali. ${ }^{1}$ Banyak pujangga Bali melahirkan geguritan dengan berbagai judul yang berbeda dan semua geguritan tersebut masih tetap eksis hingga hari ini. Contohnya Geguritan Pan Bungling, Geguritan Sudhamala, Geguritan Ki Balian Batur, Geguritan Pan Balang Tamak, Geguritan Jaya Prana, Geguritan Padewasan, Geguritan Pasuk Wetu dan berbagai geguritan lainnya.

Karya seni sastra geguritan ini merupakan khazanah budaya bangsa Indonesia yang penting dan berharga. Didalamnya terkandung nilai, konsep, dan unsur pengetahuan seperti filsafat, sejarah, pengobatan (usadha), susila, astronomi, hukum, kepemimpinan, dan unsur-unsur pengetahuan lainnya yang sangat bermanfaat bagi kehidupan manusia. Geguritan yang dibudayakan didaerah Bali diciptakan oleh penulis, pengarang atau pujangga. Yang mana kebanyakan geguritan tidak tercantum nama dari penciptanya.

Kebudayaan Indonesia saat ini mulai menjadi perhatian khusus pemerintah sebagai barang promosi didunia internasional. Namun dalam eksistensi dan perkembangannya, seni tradisi lemah dari perlindungan hukumnya. Contoh perlindungan atas hasil karya seniman tradisi, perlindungan atas hasil pemikiran intelektual berupa syair, lagu, dongeng, cerita dan lain-lainnya, masih belum dibentuk perangkat hukum secara khusus. Pemahaman masyarakat adat akan pengetahuan tradisional dan ekspresi budaya tradisional sebagai warisan budaya yang dimiliki secara komunal. Konsep komunal acapkali beranggapan bahwa hasil karya intelektual adalah karya milik bersama. ${ }^{2}$ Disini muncul anggapan bahwa pengetahuan tradisional dan ekpresi budaya tradisional menjadi barang yang terbuka dan publik domein. Kondisi seperti ini akan merugikan masyarakat adat dan Negara Indonesia sendiri. Umumnya pemanfaatan pengetahuan tradisional dan ekspresi budaya tradisional dengan mudah diklaim sebagai domein pihak lain yang lebih awal mendaftarkan dan mempublikasinya.

Benturan kepentingan negara maju dengan negara berkembang mengenai pengetahuan tradisional dan ekspresi budaya tradisional harus di fasilitasi dalam perjanjian TRIPs. Negara maju berkeinginan pengetahuan tradisional sebagai publik

${ }^{1}$ Adnyana, Gede Agus Budi. (2011). Susastra Hindu Nusantara. Gandapura. Bali. h.4

2 Dharmawan, Ni KetutSupasti.. Wiryawan, Wayan., Dunia, Ngakan Ketut., dkk. (2016). Buku Ajar Hak Kekayaan Intelektual (HKI). Yogyakarta, CV Budi Utama. h.25 
domein sehingga bebas diakses, hal ini merugikan negara-negara berkembang. Sisi lain negara berkembang beranggapan HKI belum mampu melindungi kepentingan negaranya dibidang ekspresi budaya tradisional dan pengetahuan tradisional. HKI ada karena bentuk kreativitas manusia yang dikembangkan atau dipelajari terlebih dahulu sehingga muncullah suatu ide untuk menciptakan sebuah karya yang memiliki manfaat bagi banyak orang. ${ }^{3}$ Seperti pelanggaran yang pernah terjadi pada Lagu Rasa Sayange yang diklaim milik Negara Malaysia dengan cara mempublikasikan di tv bahwa lagu itu adalah milik negaranya dengan dijadikan iklan negara. Padahal sudah jelas Lagu Rasa Sayange milik Negara Indonesia. Inilah sebab pengaturan hukum menjadi urgen untuk melindungi ekspresi budaya tradisional dan pengetahuan tradisional yang memiliki aturan yang absurd.

Geguritan sebagai ekspresi budaya tradisional dan pengetahuan tradisional selayaknya mendapatkan perlindungan hukum yang pasti di Indonesia. UndangUndang Nomor 28 Tahun 2014 tentang Hak Cipta mengatur ekspresi budaya tradisional dan ciptaan yang dilindungi. Salah satu upaya perlindungan hukum tercantum pada Bab V Bagian Kesatu mengenai Ekspresi Budaya Tradisional dan Hak Cipta atas Ciptaan yang Penciptanya Tidak Diketahui, Pasal 38 ayat (1) menyatakan bahwa Hak Cipta atas ekspresi budaya tradisional dipegang oleh Negara, dan Ayat (2) menyatakan bahwa Negara wajib menginventarisasi, menjaga, dan memelihara ekspresi budaya tradisional sebagaimana dimaksud pada ayat (1). Serta pada Pasal 39 ayat (1) yang menyatakan bahwa Dalam hal Ciptaan tidak diketahui Penciptanya dan Ciptaan tersebut belum dilakukan Pengumuman, Hak Cipta atas Ciptaan tersebut dipegang oleh Negara untuk kepentingan Pencipta. Seringnya terjadi pelanggaran terhadap penggunaan pengetahuan tradisional masyarakat adat, memuculkan adanya kesadaran komunal akan keberadaan dan pengakuan atas hak intelektual dari masyarakat adat sebagai warisan leluhur, sedangkan didalamnya juga terdapat hak individu sebagai pencipta namun hingga kini perlindungan terhadap hak individu pada Undang-Undang Hak Cipta masih lemah karena tidak bisa membuktikan siapa penciptanya. Hal inilah yang membangkitkan kesadaran perlindungan hak atas kekayaan intelektual atas pengetahuan tradisional dan ekspresi budaya tradisional yang dimiliki masyarakat adat.

Dari paparan masalah diatas maka diangkatlah karya ilmiah yang berjudul Geguritan Bali Dalam Perlindungan Undang-Undang Hak Cipta Indonesia. Dengan rincian rumusan masalah yaitu; Bagaimanakah perlindungan hukum Geguritan Bali menurut Undang-Undang No.28 Tahun 2014 tentang Hak Cipta? Apakah upaya hukum yang dapat dilakukan apabila Geguritan Bali diperbanyak tanpa izin guna kebutuhan komersial?. Tujuan dilaksanakannya penelitian ini adalah mengingat perlindungan hak cipta terhadap karya-karya seniman tradisional khususnya geguritan Bali selama ini sangat lemah. Sehingga sering terjadi pelanggaran hak cipta dengan cara deklarasi pengakuan oleh pihak lain bahwa karya tradisional itu miliknya. Oleh sebab itu maka tulisan ini akan meneliti dan mengkaji lebih lanjut dari perspektif hukum Hak Cipta Indonesia mengenai perlindungan karya-karya seniman tradisional khususnya Geguritan Bali.

\footnotetext{
${ }_{3}^{3}$ Simangunsong, H. L., Santoso B., \& Lumbanraja, A.D. Perlindungan Hak Cipta Terhadap Pembajakan Kary a Sastra Novel VersiE-Book Di Tokopedia. Notarius, 13(2), 442-454.
} 
Sebelumnya terdapat penelitian yang mirip dengan tulisan ini, yaitu penelitian dari Dyah Permata Budi Asri dengan judul "Pelindungan Hukum Preventif Terhadap Ekspresi Budaya Tradisional Di Daerah Istimewa Yogyakarta Berdasarkan UndangUndang Nomor 28 Tahun 2014 Tentang Hak Cipta", yang memiliki fokus objek penelitiannya adalah mengenai perlindungan hukum ekspresi budaya tradisional di Daerah Istimewa Yogyakarta. Kemudian terdapat pula penelitian yang mirip yaitu penelitian dari Dewa Ayu Dian Sawitri dengan judul "Perlindungan Transformasi Karya Cipta Lontar Dalam Bentuk Digitalisasi", yang memiliki fokus objek penelitiannya adalah perlindungan transformasi karya cipta lontar dalam bentuk digitalisasi serta mengelaborasi mekanisme legalisasi pentransformasian dari karya yang awalnya dalam bentuk lontar. Membandingkan secara seksama kedua penelitian dari Dyah Permata Budi Asri dan Dewa Ayu Dian Sawitri memiliki rumusan masalah serta topik pembahasan yang berbeda dengan tulisan ini. Dimana Tulisan ini memfokuskan pada perlindungan hak cipta geguritan Bali serta upaya hukum yang dapat ditempuh bila terjadi pelanggaran Hak Cipta, sehingga tulisan ini memiliki orisinalitas tersendiri dalam kajian penelitian hukum.

\section{Metode Penelitian}

Penulisan jurnal hukum ini menggunakan metode penelitian yuridis normatif. Sedangkan jenis pendekatakan yang penulis gunakan ialah pendekatan perundangundangan (The Statue Approach) dan pendekatatan analisis konsep hukum. ${ }^{4}$ Pendekatan perundang-undangan, digunakan karena yang penulis teliti adalah aturan hukum yaitu Undang-Undang No.28 Tahun 2014 tentang Hak Cipta yang menjadi fokus sentral dalam penelitian ini. Selanjutnya dilanjutkan dengan menganalisis permasalahan yang ada sesuai dengan konsep-konsep hukum yang disertai dengan berbagai literatur seperti buku-buku, jurnal, artikel, dan lain sebagainya, yang relevan dengan judul yang penulis angkat. Teknik analisis yang digunakan yaitu deskripsi, interprestasi dan argumentasi. ${ }^{5}$

\section{Hasil dan Pembahasan}

\subsection{Pengaturan Perlindungan Karya Sastra Geguritan Bali Dalam Undang-Undang Hak Cipta Indonesia.}

Word Intellectual Property Organization atau selanjutnya dsingkat dengan WIPO memberikan definisi pengetahuan tradisional, ${ }^{6}$ bertolak pada sastra yang berupa karya seni atau ilmiah; pementasan; invensi; penemuan ilmiah; desain; merek; nama dan simbol-simbol; rahasia dagang dan inovasi-inovasi yang berupa budaya dan ciptaanciptaan yang merupakan hasil kegiatan intelektual dalam bidang industri, ilmu pengetahuan, seni dan sastra.

\footnotetext{
${ }^{4}$ Marzuki, Peter Mahmud. (2010). Penelitian Hukum. Jakarta. Kencana Prenada Media Group. h.93

${ }^{5}$ Dirgantara. P. (2019). Tanggung Jawab Saksi Pengenal Terhadap Keterangan yang Diberikan dalam Pembuatan Akta Autentik. Acta Comitas. 4(2). 187-197.

${ }^{6}$ Darusman, Y. M. (2016). Kedudukan Serta Perlindungan Hukum bagi Pemegang Hak Paten dalam Kerangka Hukum Nasional Indonesia dan Hukum Internasional. Yustisia Jurnal Hukum, 5(1), 202-215.
} 
Perlindungan Ekspresi Budaya Tradisional pada dunia internasional dimulai oleh World Intellectual Property Organization (WIPO) tahun 1976 dengan mengembangkan The Tunis Model Law on Copyright (Tunis Model Law). Setelah Tunis Model Law, pada tahun 1982 WIPO dan United Nations on Education Social and Cultural Organization (UNESCO) menciptakan suatu instrument dalam perlindungan ekspresi budaya tradisional dengan menyusun The Model Provisions for National Laws on the Protection of Expressions of Ekspresi Budaya Tradisional Against Illicit Exploitation and Other Prejudicial Actions (Model Provisions). ${ }^{7}$ Model Provisions berisi substansi yang bersifat sui generis dalam perlindungan ekspresi budaya tradisional. Model Provisions disebut sebagai dasar yang mungkin untuk pengaturan standar ekspresi budaya tradisional masa depan pada tingkat internasional. ${ }^{8}$

Penjelasan diatas memberikan pencerahan bahwa suatu karya sastra dikualifikasikan kedalam Ekspresi Budaya Tradisional. Geguritan Bali merupakan salah satu bagian dari karya sastra yang adi luhung, diwariskan secara turun-temurun oleh leluhur orang Bali. ${ }^{9}$ Setiap bait kalimat yang tercantum dalam geguritan Bali mengandung nilai ekspresi budaya tradisional orang-orang Bali. Roh dari budaya tradisional orang Bali khususnya geguritan Bali ini adalah agama Hindu. Sehingga karya sastra geguritan Bali memiliki sifat unik dan khas tersendiri yang membedakan dengan karya sastra daerah lainnya.

Seorang pujangga sebagai pencipta dengan menggali nilai, merumuskan aturan dan menyusun geguritan Bali membutuhkan pengorbanan waktu, tenaga, rasa dan pikiran dalam menghasilkan suatu karya sastra. Orang yang mampu mempekerjaan otaknya yang dapat menghasilkan hak kebendaan yang sebut sebagai "Intellectual Property Rights", itu sebabnya hasil kerja otak yang membuahkan hak atas kekayaan intelektual bersifat eksklusif dan mendapat perlindungan hukum. ${ }^{10}$ Perlindungan hukum terhadap hasil karya sastra geguritan Bali diatur dalam Undang-Undang Nomor 28 Tahun 2014 tentang Hak Cipta, pada Bab V mengenai Ekspresi Budaya Tradisional dan Ciptaan Yang Dilindungi Pasal 38 sampai dengan Pasal 42. Dalam Pasal 38 UndangUndang Nomor 28 Tahun 2014 tentang Hak Cipta, menyebutkan bahwa :(1) Hak Cipta atas ekspresi budaya tradisional dipegang oleh Negara. (2) Negara wajib menginventarisasi, menjaga, dan memelihara ekspresi budaya tradisional sebagaimana dimaksud pada ayat (1).

Masyarakat hukum adat dewasa ini memiliki kesadaran bahwa mengenai karya sastra geguritan Bali memberikan hak komunal dan pengakuan atas hak kekayaan

\footnotetext{
7 Prabhawa, Cok Gede Agung Wirahadi. (2017). UPAYA PENYELESAIAN SENGKETA HAK ATAS KEKAYAAN INTELEKTUAL ANTARA INDONESIA DENGAN MALAYSIA TERKAIT PENJIPLAKAN KARYA SASTRA GEGURITAN SANG CANGAK DALAM PERSPEKTIF HUKUM INTERNASIONAL. Kertha Negara. 5 (2). 1-5.

8 PUTRAYANA, I. K. W., \& DARMADHA, I. N. PERLINDUNGAN HUKUM TERHADAP EKSPRESI BUDAYA TRADISONAL INDONESIA DALAM UNDANG-UNDANG NOMOR 28 TAHUN 2014. Kertha Semaya: Journal Ilmu Hukum, 4(2), 1-14.

9 Suarta, I. M. (2013). KEARIFAN LOKAL (LOCAL GENIUS) SEBAGAI SOKO GURU MENATA PERADABAN BANGSA YANG BERKARAKTER NUSANTARA (REFLEKSI KARYA KI DALANG TANGSUB). Jurnal IKADBUDI, 2(12).

10 Soelistya, Henry. (2014). Hak Kekayaan Intelektual Konsepsi. Opini dan Aktualisasi. Jakarta Selatan, Penaku. h.13
} 
intelektual dari masyarakat adat sebagai warisan budaya secara turun temurun. Sedangkan di lain sisi dari hasil karya sastra geguritan Bali mempunyai hak individual yang dimilikki oleh pujangga yang menciptakan geguritan tersebut. Hak individu dimiliki setiap Pencipta yang ditunjukkan pada pengertian Hak Cipta sesuai Pasal 1 angka 1 Undang-Undang Nomor 28 Tahun 2014 Tentang Hak Cipta, bahwa hak Cipta adalah hak eksklusif pencipta yang timbul secara otomatis berdasarkan prinsip deklaratif setelah suatu ciptaan diwujudkan dalam bentuk nyata tanpa mengurangi pembatasan sesuai dengan ketentuan peraturan perundang-undangan. Pasal 4 menyatakan Hak Cipta sebagaimana dimaksud dalam Pasal 3 huruf a merupakan hak eksklusif yang terdiri atas hak moral dan hak ekonomi. Kemudian pada Pasal 5 ayat (1) huruf a dan b yang menyatakan bahwa :

(1) Hak moral sebagaimana dimaksud dalam Pasal 4 merupakan hak yang melekat secara abadi pada diri Pencipta untuk:

a. tetap mencantumkan atau tidak mencantumkan namanya pada salinan sehubungan dengan pemakaian Ciptaannya untuk umum;

b. menggunakan nama aliasnya atau samarannya;

Namun kebanyakan karya sastra geguritan Bali yang diciptakan, tidak mencantumkan nama pencipta. Apalagi nama pencipta, bahkan inisial dari pencipta pun tidak dicantumkan pada hasil karya sastra geguritan Bali. Berkenaan dengan hal tersebut Undang-Undang Nomor 28 Tahun 2014 Tentang Hak Cipta telah mengatur mengenai Ekspresi Budaya Tradisional yang penciptanya tidak diketahui identitasnya, yaitu pada Pasal 39 ayat (1) yang berbunyi: Dalam hal ciptaan tidak diketahui penciptanya dan ciptaan tersebut belum dilakukan pengumuman, Hak Cipta atas Ciptaan tersebut dipegang oleh negara untuk kepentingan pencipta. Terkadi kekaburan norma pada pasal tersebut karena pada bagian penjelasan Undang-Undang Nomor 28 Tahun 2014 tentang Hak Cipta Pasal 39 ayat (1) cukup jelas. Pertanyaan selanjutnya siapakah negara yang simaksud dan sejauh mana kewenangan negara dalam memegang hak cipta atas pencipta yang tidak diketahui itu. Hal tersebut menjadi perdebatan hingga saat ini. Kekaburan norma tampak karena tidak ditentukan secara jelas negara dalam artian siapa yang berhak memegang ciptaan tersebut. Sedangkan Undang-Undang Nomor 28 Tahun 2014 tentang Hak Cipta menekankan perlindungan kepada Pencipta yang namanya harus dicantumkan.

Negara sebagai lembaga yang memiliki otoritas tertinggi, dan pemerintah daerah sebagai representasi negara dalam perlindungan dan pengaturan ekspresi budaya tradisional dapat mencegah adanya pemanfaatan komersialisasi oleh pihak asing tanpa seizin negara sebagai pemegang Hak Cipta. ${ }^{11}$ Pada pasal 60 ayat (1) UndangUndang Nomor 28 Tahun 2014 Tentang Hak Cipta disebutkan, Hak Cipta atas ekspresi budaya tradisional yang dipegang oleh negara sebagaimana dimaksud pasal 38 ayat (1) berlaku tanpa batas waktu. Pasal ini jelas memiliki tujuan melindungi karya-karya tradisional.

Meskipun tujuan dari pasal 60 ayat (1) ini adalah untuk melindungi karya-karya intelektual berupa budaya, adat istiadat maupun nilai-nilai budaya yang terkandung

11 Asri, D. P. B. (2017). Model Kebijakan Strategis Terhadap Pelestarian Kebudayaan Lokal 'Merti Code'Sebagai Aset Daerah Untuk Meningkatkan Sektor Pariwisata Berbasis Budaya. Jurnal Jarlit, 10. 
dalam masyarakat asli, akan sulit bagi masyarakat tradisional untuk menggunakannya dalam melindungi karya-karyanya. Hal ini disebabkan oleh adanya perbedaan karakter antara Hak Kekayaan Intelektual dan ekspresi budaya tradisional yang membuat sistem hukum Kekayaan Intelektual belum mampu melindungi Ekspresi Budaya Tradisional secara utuh.

Dalam konsep Hak Kekayaan Intelektual khususnya dalam Undang-Undang Hak Cipta, pemberian perlindungan terhadap Ekspresi Budaya Tradisional berbeda dengan pemberian perlindungan pada jenis hak cipta lain seperti buku, lagu, atau pun lukisan. Hal ini dikarenakan terhadap Ekspresi Budaya Tradisional tersebut kepemilikannya bukan bersifat individu seperti halnya pada karya cipta buku, lagu, ataupun lukisan tersebut. Namun, kepemilikan Ekspresi Budaya Tradisional tersebut merupakan kepemilikan secara komunal. Ini berarti bahwa Ekspresi Budaya Tradisional dimiliki oleh sekelompok masyarakat adat pada suatu daerah atau tempat tertentu.

Selain itu, pencipta Hak Kekayaan Intelektual teridentifikasi secara jelas dan orientasi ciptaannya lebih mengarah kedalam motif ekonomi (mencari keuntungan), sedangkan dalam Ekspresi Budaya Tradisional, identifikasi pencipta asli tidak diketahui karena kemunculannya merupakan suatu budaya yang muncul dari tradisi lisan yang diwariskan secara turun menurun.

Perlindungan terhadap Ekspresi Budaya Tradisional, dengan melihat pada ciri-ciri yang melekat pada Ekspresi Budaya Tradisional tersebut yang sangat berbeda dengan rezim Hak Kekayaan Intelektual umumnya seperti hak cipta buku, lagu, ataupun lukisan yang sangat bersifat individualistik. Sehingga komponen perlindungan yang tepat untuk diberlakukan pada Ekspresi Budaya Tradisional perlu dibedakan dengan jenis Hak Kekayaan Intelektual umumnya. Sehingga diperlukan upaya perlindungan hukum yang bersifat preventif dan represif. ${ }^{12}$

Bahwa perlindungan HKI atas Ekspresi Budaya Tradisional di dalamnya menjadi penting dilakukan karena didasarkan pada tiga pertimbangan, yaitu: (1) Nilai ekonomi; (2) Pengembangan karakter bangsa yang terdapat dalam pengetahuan tradisional(traditional knowledge) dan folklore; (3) Pemberlakuan rezim Hak Kekayaan Intelektual yang tidak dapat dihindari lagi. ${ }^{13}$

Nilai ekonomi menjadi satu hal yang penting dalam konsep ini, karena bisa saja dengan nilai-nilai kebudayaan yang ditampakkan nantinya dapat menghasilkan keuntungan ekonomi yang bisa jadi hal itu tidak bernilai sedikit. ${ }^{14}$ Aspek lain yang juga merupakan alasan penting dalam melakukan usaha proteksi terhadap nilai-nilai folklore ini adalah bahwa seringkali keberadaan satu kebudayaan tertentu atau

12 Paramisuari, A. A. S., \& Purwani, S. P. M. (2019). Perlindungan Hukum Ekspresi Budaya Tradisional Dalam Bingkai Rezim Hak Cipta. Kertha Semaya: Journal Ilmu Hukum, 7(1), 1-16 ${ }^{13}$ Kartika, E. D. (2018). PERLINDUNGANHUKUM ATAS CERITA RAKYAT YANG DITULIS OLEH PENCIPTA DALAM RANGKA BENEFIT SHARING. Jurnal Hukum $\mathcal{E}$ Pembangunan, 48(2), 379-392.

${ }_{14}$ Ibid. 
folklore ini mampu menonjolkan identitas atau ciri khas tertentu bagi suatu daerah bahkan suatu negara sekalipun. ${ }^{15}$

Salah satu faktor utama penyebab terhambatnya penerapan HKI di Indonesia adalah masalah perbedaan konsep HKI yang individualistik dan budaya masyarakat Indonesia yang komunalistik dan mengedepankan konsep komunitas. Budaya gotong royong merupakan salah satu ciri yang menonjol dalam masyarakat Indonesia. Nilai ini telah menimbulkan konsepsi tersendiri mengenai masalah kepemilikan. ${ }^{16}$

Bagi sebagian besar masyarakat Indonesia, khususnya pemegang HKI, selama ini tidak memandang sebagai pelanggaran serius bila HKI-nya dimanfaatkan atau dipergunakan oleh orang lain, meskipun tanpa melalui izin si pemegang benda tersebut. Sedangkan konsep ini berbeda dengan HKI yang berasal dari Barat di mana dalam konsep Barat, setiap pemanfaatan atas kepemilikan seseorang dapat dianggap sebagai pelanggaran HKI apabila tidak mendapat izin dari pemiliknya secara sah. ${ }^{17}$ Indonesia memberikan perlindungan atas ciptaan yang tidak ada penciptanya (traditional knowledge/folklore) dibawah rezim Hak Cipta. Di Dalam UndangUndang Nomor 28 tahun 2014 ini disebutkan bahwa mengenai ketentuan lebih lanjut mengenai Hak Cipta yang dipegang oleh Negara atas Ekspresi Budaya Tradisional diatur dengan Peraturan Pemerintah. Namun hingga saat ini Peraturan Pemerintah yang ditunggu-tunggu sebagai upaya dalam perlindungan kebudayaan nasional tersebut belum dibuat. ${ }^{18}$

\subsection{Upaya Hukum Yang Dapat Dilakukan Apabila Geguritan Bali Di Perbanyak Tanpa Izin Guna Kebutuhan Komersial}

Konsepsi perlindungan Hak Kekayaan Intelektual sesuai dengan teori dari Robert M. Serwood ada 4 (empat) yaitu Reward Theory, Recovery Theory, Incentive Theory dan Risk Theory. ${ }^{19}$ Reward Theory bermakna karya intelektual yang telah dihasilkan dari seseorang pencipta harus diberikan penghargaan sebagai imbalan atas usahanya menciptakan karya intelektual tersebut. Seorang Pujangga Bali membuat karya sastra geguritan memang diciptakan dari hasil cipta, rasa dan karsa diri sendiri sehingga mempunyai isi, judul, tema dan karateristik bahasa yang berbeda dengan geguritan lainnya. Recovery Theory menyatakan pencipta yang telah mengorbankan waktu, biaya serta tenaga untuk menghasilkan karya intelektualnya harus memperoleh kembali apa yang telah dikeluarkannya. Seorang Pujangga Bali sudah tentu dalam menciptakan geguritan membutuhkan waktu, biaya dan tenaganya dalam proses penciptaannya. Tidak jarang untuk menghasilkan geguritan yang memiliki kualitas bagus dan memiliki daya tarik, dalam bahasa Bali disebut dengan "taksu". Maka seorang pujangga membutuhkan waktu puluhan tahun, setengah umur hidupnya sampai seluruh umur hingga akhir hayatnya untuk menciptakan satu karya geguritan. Incentive Theory memiliki makna bahwa insentif perlu diberikan untuk memberikan

\footnotetext{
${ }^{15}$ Ibid. h. 384

${ }_{16}$ Ibid

${ }^{17} \mathrm{Ibid}$

18 Ibid. h. 384-385.

${ }^{19}$ Asyfiyah, S. (2015). Perlindungan Hukum Potensi IndikasiGeografis Di Kabupaten Brebes Guna Pengembangan Ekonomi Masyarakat Lokal. Jurnal Idea Hukum, 1(2).111-124.
} 
dorongan terpacunya kegiatan penciptaan-penciptaan yang berguna. Penciptaan geguritan Bali memiliki daya guna yang besar selain sebagai karya cipta yang mampu dipertontonkan juga sebagai bahan ilmu pengetahuan budaya yang adi luhung bagi generasi ke generasi. Teori yang terakhir yaitu Risk Theory bermakna bahwa penciptaan Hak Kekayaan Intelektual mengandung resiko yang dapat memungkinkan orang lain yang lebih dahulu menemukan cara atau memperbaikinya, dengan demikian adalah penting memberikan perlindungan hukum kegiatan penciptaan yang mengandung resiko tersebut terkhusus dalam pembahasan ini yaitu penciptaan geguritan Bali.

Undang-Undang Nomor 28 Tahun 2014 tentang Hak Cipta Pasal 38 ayat (4) menentukan mengenai hak cipta yang dipegang oleh negara atas Ekspresi Budaya Tradisional sebagaimana dimaksud pada Pasal 38 ayat (1) diatur oleh peraturan pemerintah. Berarti pihak yang menjadi pemegang hak cipta atas geguritan bali sebagai salah satu hasil dari ekspresi budaya tradisional dipegang oleh negara. Pemerintahan negara sebagai pemegang otoritas tertinggi dalam suatu sistem pemerintahan dimana kebudayaan itu lahir adalah pemerintah daerah. Sebagai pemegang Hak Cipta Ekpresi Budaya Tradisional mendapatkan hak-hak eksklusif atas karya cipta tersebut. Hak-hak eksklusif yang diberikan oleh Undang-Undang Hak Cipta adalah hak untuk menerbitkan, menggandakan, menerjemahkan, mengadaptasi, mengaransemen, mentransformasikan, mendistribusikan, mempertunjukan, mengumumkan, mengkomunikasikan dan menyewakan ciptaan. Rumusan diatas memberikan arti bahwa undang-undang memberikan kewenangan kepada pemerintah daerah untuk mengatur hak cipta tersebut. 20

H.D. Stout memberikan pengertian kewenangan merupakan pengertian yang berasal dari hukum organisasi pemerintahan, yang dapat dijelaskan sebagai seluruh aturanaturan yang berkenaan dengan perolehan dan penggunaan wewenang-wewenang pemerintahan oleh subjek hukum publik didalam hubungan hukum publik. Hak Menguasai Negara(state control right) merupakan negara mempunyai kekuasaan (power) atau kewenangan (authority) yang berdasarkan hukum untuk mengatur, mengurus dan mengawasi. ${ }^{21}$ Hak mempunyai arti kewenangan, kekuasaan guna berbuat sesuatu karena telah ditentukan peraturan perundang-undangan.

Undang-Undang Pemerintahan Daerah pada Pasal 1 ayat (6) menentukan bahwa otonomi adalah hak, wewenang dan kewajiban daerah otonom untuk mengatur dan mengurus sendiri urusan pemerintahan dan kepentingan masyarakat setempat dalam sistem Negara Kesatuan Republik Indonesia. Prinsip dari konsep pelaksanaan otonomi daerah merupakan usaha memaksimalkan hasil yang dicapai dan menghindari kerumitan dan hal-hal yang menghambat kemajuan daerah. Adanya sistem otonomi ini diharapkan daerah-daerah lebih mandiri dalam menentukan seluruh kegiatannya. Pemerintahan daerah diharapkan mampu memainkan peranannya dalam membuka

${ }^{20}$ Hasima. R. (2018). Perlindungan Hukum Terhadap Ekspresi Budaya Tradisional Masyarakat Adat Tolaki. Literasi Hukum. 2(1). 15-27.

${ }^{21}$ Sembiring, J. (2016). Hak menguasainegara atas sumber daya agraria. BHUMI: Jurnal Agraria dan Pertanahan, 2(2), 119-132. 
peluang memajukan kebudayaan daerah dengan menggali potensi budaya terutama budaya yang berbentuk Ekpresi Budaya Tradisional. ${ }^{22}$

Tanggung jawab perlindungan Ekpresi Budaya Tradisional sangat berkaitan dengan daerah sebagai tempat budaya itu lahir dan diemban, sehingga pemerintah daerah baik provinsi, kota maupun kabupaten memegang tugas dan fungsi penting dalam perlindungannya. Upaya hukum yang dapat ditempuh pemerintah daerah bila terjadi pelanggaran adalah gugatan atas karya cipta Geguritan Bali yang diperbanyak tanpa izin guna kebutuhan komersial. Berkenaan tata cara mengajukan gugatan telah diatur dalan Bab XIV Undang-Undang Nomor 28 Tahun 2014 tentang Hak Cipta pada Pasal 95 ayat (1) menentukan penyelesaian sengketa hak cipta dapat dilakukan melalui alternatif penyelesaian sengketa, arbitrase atau pengadilan. Pada ayat (2) mengenai pengadilan yang berwenang mengadili sengketa itu adalah Pengadilan Niaga. Kemudian pada Pasal 97 menentukan bahwa: (1) Dalam Hal Ciptaan yang telah dicatat menurut ketentuan Pasal 69 ayat (1), pihak lain yang berkepentingan dapat mengajukan gugatan pembatalan pencatatan Ciptaan dalam daftar umum Ciptaan melalui Pengadilan Niaga; ayat (2) gugatan yang dimaksud ayat (1) ditujukan kepada Pencipta dan/atau Pemegang Hak Cipta terdaftar.

Pemerintah daerah sebagai pihak yang berwenang mengajukan gugatan dilihat dari teori kewenangan, salah satu kewenangan pemerintah daerah yang dapat digunakan adalah mandat. Mandat dilakukan ketika organ pemerintahan mengizinkan kewenangannya dijalankan oleh organ lain atas namanya. ${ }^{23}$ Dimana mandat itu dapat diberikan oleh negara yang mengizinkan kewenangannya dijalankan oleh or gan lain atas namanya, yang dalam hal ini yaitu pemerintah daerah kepada Dinas Kebudayaan Provinsi maupun Dinas Kebudayaan Kota/Kabupaten.

Senyatanya peraturan perundang-undangan pemerintahan daerah tidak eksplisit memberikan keterkaitan antara otonomi daerah dengan sistem hukum Hak Kekayaan Intelektual. Namun seiring perkembangan teknologi yang begitu cepat dan tantangan persaingan dunia glogal, pemerintah daerah diharapkan mampu mengelola serta melindungi Ekspresi Budaya Tradisional masyarakat adatnya berdasarkan otonomi daerah dan prinsip-prinsip Hak Kekayaan Intelektual. Konsep perlindungan Ekspresi Budaya Tradisional erat kaitanya dengan daerah pengemban budaya itu, sehingga pemerintahan daerah baik provinsi, kota maupun kabupaten memegang tanggung jawab penting dalam perlindungannya. ${ }^{24}$ Perlindungan terhadap Ekspresi Budaya Tradisional ini berkaitan dengan peran negara sebagai usaha mewujudkan tujuan negara. Terjaminnya perlindungan hukum yang diberikan oleh negara dapat mendorong peningkatan kesejahteraan seluruh masyarakat dan khususnya sastrawan pencipta Geguritan Bali. 25

22 Idriaty. J. (2015). Perlindungan Hukum Ekspresi Budaya Tradisional oleh Negara Sebagai Pemegang Hak Cipta Kekayaan Intelektual Komunal Masyarakat Sulawesi Tenggara Dikaitkan Dengan Hak Ekonomi Berdasarkan Undang-Undang Nomor 28 Tahun 2014 tentang Hak Cipta (Doctoral dissertation. Thesis. Magister Hukum Universitas Padjajaran Bandung).

${ }^{23}$ Ibid.h.102

${ }^{24}$ Asri, Dyah Permata Budi. (2018). Perlindungan Hukum Terhadap Kebudayaan Melalui World Heritage Centre UNESCO. Jurnal Hukum IUS QUIA IUSTUM 25 (2), MEI 2018: 256 - 276.

${ }^{25}$ Idriaty J. loc.cit. 
Geguritan Bali dapat dipergunakan oleh pihak lain dengan tetap memperhatikan hak moral penciptanya dalam hal ini daerah asal atau negara sebagai pemegang hak cipta Geguritan Bali. Dengan fair use Geguritan Bali dapat dipergunakan oleh siapapun dengan tetap mengingat batasan-batasan dalam ketentuan hak cipta, tetapi keasliannya akan tetap mendapatkan perlindungan karena disebutkannya daerah asal geguritan tersebut. Sehingga Geguritan Bali akan tetap eksis keasliannya walaupun dipertunjukan didalam maupun luar negeri baik dengan kepentingan komersial maupun non komersial.

\section{Kesimpulan}

Perlindungan karya cipta Geguritan Bali sebagai Ekspresi Budaya Tradisional dalam Undang-Undang Nomor 28 Tahun 2014 tentang Hak Cipta belum mampu melindungi Ekspresi Budaya Tradisional secara utuh karena adanya kekaburan norma serta perbedaan karakter antara Hak Kekayaan Intelektual dan Ekspresi Budaya Tradisional.

Pemerintah Daerah mempunyai kewenangan mengajukan gugatan terkait dengan perbanyakan Geguritan Bali tan izin untuk kebutuhan komersial. Berdasarkan teori kewenangan mandat yang diberikan negara sebagai pemegang Hak Cipta atas Ekpresi Budaya Tradisional kepada Dinas Kebudayaan Provinsi maupun Dinas Kebudayaan Kabupaten Kota sebagai daerah pengemban Ekspresi Budaya Tradisional.

\section{Daftar Pustaka}

Adnyana, Gede Agus Budi. (2011). Susastra Hindu Nusantara. Bali, Gandapura.

Dharmawan, Ni Ketut Supasti.. Wiryawan, Wayan., Dunia, Ngakan Ketut., dkk. (2016). Buku Ajar Hak Kekayaan Intelektual (HKI). Yogyakarta, CV Budi Utama.

Soelistya, Henry. (2014). Hak Kekayaan Intelektual Konsepsi. Opini dan Aktualisasi. Jakarta Selatan, Penaku.

Marzuki, Peter Mahmud. (2010). Penelitian Hukum. Jakarta. Kencana Prenada Media Group.

\section{Jurnal}

Asri, D. P. B. (2017). Model Kebijakan Strategis Terhadap Pelestarian Kebudayaan Lokal 'Merti Code'Sebagai Aset Daerah Untuk Meningkatkan Sektor Pariwisata Berbasis Budaya. Jurnal Jarlit, 10.

Asyfiyah, S. (2015). Perlindungan Hukum Potensi Indikasi Geografis Di Kabupaten Brebes Guna Pengembangan Ekonomi Masyarakat Lokal. Jurnal Idea Hukum, 1(2). 111-124.

Asri, Dyah Permata Budi. (2018). Perlindungan Hukum Terhadap Kebudayaan Melalui World Heritage Centre UNESCO. Jurnal Hukum IUS QUIA IUSTUM 25 (2), MEI 2018: $256-276$. 
Dirgantara. P. (2019). Tanggung Jawab Saksi Pengenal Terhadap Keterangan yang Diberikan dalam Pembuatan Akta Autentik. Acta Comitas. 4(2). 187-197.

Darusman, Y. M. (2016). Kedudukan Serta Perlindungan Hukum bagi Pemegang Hak Paten dalam Kerangka Hukum Nasional Indonesia dan Hukum Internasional. Yustisia Jurnal Hukum, 5(1), 202-215.

Hasima. R. (2018). Perlindungan Hukum Terhadap Ekspresi Budaya Tradisional Masyarakat Adat Tolaki. Literasi Hukum. 2(1). 15-27.

Kartika, E. D. (2018). PERLINDUNGAN HUKUM ATAS CERITA RAKYAT YANG DITULIS OLEH PENCIPTA DALAM RANGKA BENEFIT SHARING. Jurnal Hukum $\mathcal{E}$ Pembangunan, 48(2), 379-392.

Prabhawa, Cok Gede Agung Wirahadi. (2017). UPAYA PENYELESAIAN SENGKETA HAK ATAS KEKAYAAN INTELEKTUAL ANTARA INDONESIA DENGAN MALAYSIA TERKAIT PENJIPLAKAN KARYA SASTRA GEGURITAN SANG CANGAK DALAM PERSPEKTIF HUKUM INTERNASIONAL. Kertha Negara. 5 (2). $1-5$.

PUTRAYANA, I. K. W., \& DARMADHA, I. N. PERLINDUNGAN HUKUM TERHADAP EKSPRESI BUDAYA TRADISONAL INDONESIA DALAM UNDANGUNDANG NOMOR 28 TAHUN 2014. Kertha Semaya: Journal Ilmu Hukum, 4(2), 1-14.

Paramisuari, A. A. S., \& Purwani, S. P. M. (2019). Perlindungan Hukum Ekspresi Budaya Tradisional Dalam Bingkai Rezim Hak Cipta. Kertha Semaya: Journal Ilmu Hukum, 7(1), 1-16

Simangunsong, H. L., Santoso B., \& Lumbanraja, A.D. Perlindungan Hak Cipta Terhadap Pembajakan Karya Sastra Novel Versi E-Book Di Tokopedia. Notarius, 13 (2), 442-454.

Suarta, I. M. (2013). KEARIFAN LOKAL (LOCAL GENIUS) SEBAGAI SOKO GURU MENATA PERADABAN BANGSA YANG BERKARAKTER NUSANTARA (REFLEKSI KARYA KI DALANG TANGSUB). Jurnal IKADBUDI, 2(12).

Sembiring, J. (2016). Hak menguasai negara atas sumber daya agraria. BHUMI: Jurnal Agraria dan Pertanahan, 2(2), 119-132.

\section{Tesis}

Idriaty. J. (2015). Perlindungan Hukum Ekspresi Budaya Tradisional oleh Negara Sebagai Pemegang Hak Cipta Kekayaan Intelektual Komunal Masyarakat Sulawesi Tenggara Dikaitkan Dengan Hak Ekonomi Berdasarkan Undang-Undang Nomor 28 Tahun 2014 tentang Hak Cipta (Doctoral dissertation. Thesis. Magister Hukum Universitas Padjajaran Bandung).

\section{Perundang-Undangan}

Undang-Undang Dasar Negara Republik Indonesia Tahun 1945 
Undang-Undang Nomor 28 Tahun 2014 tentang Hak Cipta, Lembaran Negara Republik Indonesia Nomor 266 Tahun 2014. 